\title{
The role of regulatory $T$ cells, interleukin-10 and in vivo scintigraphy in autoimmune and idiopathic diseases - Therapeutic perspectives and prognosis
}

\author{
Patrícia lima Falcão ${ }^{1 *}$, Tarcisio Passos Ribeiro de Campos² \\ ${ }^{1}$ PhD, PDS Researcher, Departament of Nuclear Engineering, Program of Nuclear Science and Techniques, Universidade Federal de Minas Gerais (UFMG), Belo Horizonte, MG, Brazil \\ ${ }^{2}$ PhD, Full Professor, Departament of Nuclear Engineering, Program of Nuclear Science and Techniques, UFMG, Belo Horizonte, MG, Brazil
}

Study conducted at Departament of Nuclear Engineering, Program of Nuclear Science and Techniques, Universidade Federal de Minas Gerais (UFMG), Belo Horizonte, MG, Brazil

Article received: $4 / 3 / 2017$ Accepted for publication: 5/7/2017

*Correspondence: Universidade Federal de Minas Gerais (UFMG), Escola de Engenharia, Departamento de Engenharia Nuclear Address: Av. Antônio Carlos, 6.627, bloco 4 , sala 2.285 Belo Horizonte, MG - Brazil Postal code: 31270-901 patricialfalcao@gmail.com

http://dx.doi.org/10.1590/1806-9282.63.12.1090

\section{SUMMARY}

Previous studies have demonstrated the expression of the CD25 marker on the surface of naturally occurring $\mathrm{T}$ cells $\left(\mathrm{T}_{\text {regs }}\right)$ of mice, which have a self-reactive cellular profile. Recently, expression of other markers that aid in the identification of these cells has been detected in lymphocyte subtypes of individuals suffering of autoimmune and idiopathic diseases, including: CD25, CTLA-4 (cytotoxic T-lymphocyte antigen 4), HLA-DR (human leukocyte antigen) and Interleukin 10 (IL-10), opening new perspectives for a better understanding of an association between such receptors present on the cell surface and the prognosis of autoimmune diseases. The role of these molecules has already been described in the literature for the modulation of the inflammatory response in infectious and parasitic diseases. Thus, the function, phenotype and frequency of expression of the $\alpha$-chain receptor of IL-2 (CD25) and IL-10 in lymphocyte subtypes were investigated. Murine models have been used to demonstrate a possible correlation between the expression of the CD25 marker (on the surface of CD4 lymphocytes) and the control of self-tolerance mechanisms. These studies provided support for the presentation of a review of the role of cells expressing IL-2, IL-10, HLA-DR and CTLA- 4 receptors in the monitoring of immunosuppression in diseases classified as autoimmune, providing perspectives for understanding peripheral regulation mechanisms and the pathophysiology of these diseases in humans. In addition, a therapeutic approach based on the manipulation of the phenotype of these cells and ways of scintigraphically monitoring the manifestations of these diseases by labeling their receptors is discussed as a perspective. In this paper, we have included the description of experiments in ex vivo regulation of IL-10 and synthesis of thio-sugars and poly-sugars to produce radiopharmaceuticals for monitoring inflammation. These experiments may yield benefits for the treatment and prognosis of autoimmune diseases.

Keywords: $\mathrm{T}_{\text {reg }}$ cells, IL-10, autoimmunity, idiopathies, scintigraphy.

\section{INTRODUCTION}

The immune system is orchestrated by a complex network of components interconnected by cells with their various receptors, secreted mediators, expressed molecules, activated biochemical pathways and other components that, together and at different anatomical sites, enable the body to respond to different antigenic stimuli. ${ }^{1,2}$ Generally, the responses are triggered by the interaction of exogenous antigens with the antigen-presenting cells, strategically addressed and responsible for antigen capture, transport and processing. Often, the defense strategy becomes permanent, conferring an immunological memory, capable of ensuring better response efficiency in later exposures. ${ }^{1,2}$

With the diversity of potential antigenic exposures, only a highly adaptive immune system is able to distinguish and respond to the various antigenic sequences found. The rationale for recognition of this system is the product of random recombination of gene segments that 
generate lymphocytes with enormous receptor diversity. Such receptors characterize the cell phenotype of the lineage. The type and number of receptors are directly linked to the response to the different antigens $(\mathrm{Ag})$.

The functions of the immune system include regulatory abilities, the mechanism responsible for ensuring that responses to antigens do not reach pathological and inhibitory levels, so that the immune system is not unduly activated against its own antigens, producing autoimmune disorders. Central tolerance is induced in the primary lymphoid organs, as a consequence of the recognition of autoantigens by immature $\mathrm{T}$ lymphocytes. To perform the proper protective function, multiple T-cell clones with wide antigen recognition diversity undergo a rigorous selection and thymic maturation process that occurs by recognizing their own peptides linked to major histocompatibility complex (MHC) molecules. The ability to distinguish between self and non-self antigens is defined as immunological tolerance and is critical to avoid intense self-recognition that can lead to pathological autoimmune responses. Therefore, autoreactive thymocytes that recognize autoantigens with high affinity are eliminated by clonal deletion in the thymus. ${ }^{3,4}$ While this is an efficient mechanism, it is known that some autoreactive cells can dodge this barrier and leave the thymus, and can be activated in the periphery with potential to generate autoimmunity. The fact that autoreactive cells can be detected in the periphery clearly demonstrates that the thymic selec- tion mechanism responsible for the elimination of autoreactive $\mathrm{T}$ cell clones is incomplete. ${ }^{4,5}$ In this case, how can we ensure that such autoreactive cells will not be reactivated, promoting a break in tolerance and thus the emergence of autoimmune diseases? In other words, the immune system needs different, redundant features to ensure that potential autoimmune responses do not occur.

Peripheral tolerance mechanisms have been described in $\mathrm{CD}^{+} \mathrm{T}$ cells and occur through anergy, clonal deletion and $\mathrm{T}$ cell suppression. Anergy may be induced during the Ag recognition process by $\mathrm{T}$ cells when: a) antigen presenting cells (APCs) do not express co-stimulatory molecules, thus rendering $\mathrm{T}$ cells incapable of responding to Ag; or b) when $\mathrm{T}$ cells express inhibitory receptors. In clonal deletion, there is repeated stimulation of $\mathrm{T}$ cells by antigens, resulting in cell death by apoptosis. The mechanism of suppression would be exerted by regulatory $\mathrm{T}$ cells $\left(\mathrm{T}_{\text {regs }}\right) . \mathrm{T}_{\text {regs }}$ represent a subpopulation of $\mathrm{T}$ lymphocytes characterized by the expression of $\mathrm{CD} 25^{+}$ molecules and the nuclear factor Foxp3. The Foxp3 factor induces suppression of effector $\mathrm{T}$ cells, blocking the activation and function of these lymphocytes, thus being important in the control of the immune response to self and non-self antigens. ${ }^{3}$ The activation regulation can best be understood from Figure 1.

It is possible that autoimmune disorders may be associated with failure to eliminate or inactivate high-affinity autoreactive cell clones during their ontogeny, and

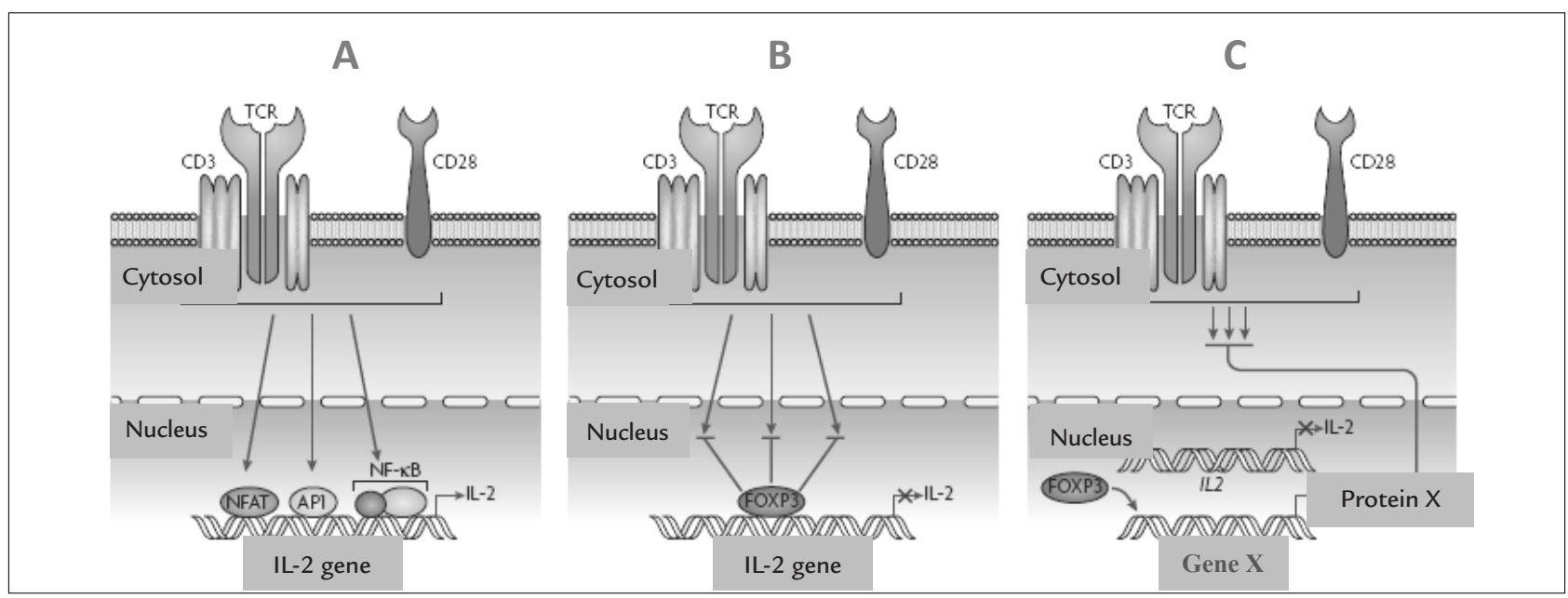

FIGURE 1 Regulation of T cell activation mediated by Foxp3. A. Signaling in effector CD4+ T cells. The binding of the T cell receptor (TCR) and the CD28 co-stimulatory molecule leads to the activation of the signaling pathways, resulting in the translocation of NFAT (nuclear factor of activated T cells) and AP1 (activator protein 1), with subsequent transcription of the IL-2 (interleukin 2) gene. B. Model of direct regulation of TCR mediated by Foxp3 signaling. In this model, the Foxp3 factor blocks TCR signaling through the inhibition of activation mediated by NFAT, $N F^{5}-\kappa B$ and AP1. C. Indirect regulation model of TCR signaling: Foxp3 factor modulates TCR signaling through the expression of a factor that can inhibit TCR-induced signals. (Adapted from Campbell and Ziegler. ${ }^{6}$ ) 
there may or may not be the failure of the immune system to control autoreactive intermediate affinity clones that have escaped to the periphery. ${ }^{5,7}$ In this context, cells with a cellular response regulation function are fundamental and are also important in the modulation of the processes of eliminating pathogen and tumor antigen. These mechanisms occur with destruction of self tissues, exposure of autoantigens and production of pro-inflammatory cytokines, which, unless regulated, favor the induction and maintenance of autoimmune events. To exercise their function, the fundamental property of $\mathrm{T}_{\text {regs }}$ is the ability to: i) produce cytokines with the cellular response modulating function of TGF- $\beta$; and ii) induce cell-cell contact-mediated suppression. These soluble substances act in a complex network of regulatory mechanisms designed to ensure the modulation of immunological responses to the various antigens derived from infectious agents, tumors, autoantigens and allergens. Among T cells, several subpopulations exhibit regulation properties for exacerbated inflammatory response, such as IL-10-producing $\mathrm{T}_{\text {regs }}$, which suppress some cytotoxic $\mathrm{T}$ cell responses in vivo, ${ }^{5,7-10}$ including: $\mathrm{CD} 8+\mathrm{CD} 28-\mathrm{T}$ cells, $\mathrm{CD} 56^{+}$ $\mathrm{T}$ cells, $\gamma \delta \mathrm{T}$ cells ${ }^{11-13}$ and CD4-CD8- T cells. ${ }^{13}$ In addition to $T$ cells, there are other cell subtypes that have been described with such properties. IL-10-producing $\mathrm{CD} 1^{+} \mathrm{B}$ cells are among them. ${ }^{14}$

Particularly among $\mathrm{T}_{\text {regs }}$, there has been a strong emphasis on naturally-occurring T cells $\left(\mathrm{CD} 4^{+} \mathrm{CD} 25^{+} \mathrm{T}\right.$ cells), as described by Sakaguchi et al. ${ }^{15}$ which are potentially capable of suppressing activation, proliferation and/or effector function of $\mathrm{CD} 4^{+}$and $\mathrm{CD} 8^{+} \mathrm{T}$ cells, and, possibly, NK cells, NK/T, B lymphocytes and dendritic cells. ${ }^{15} \mathrm{~T}_{\text {regs }}$ are indispensable for the maintenance of tolerance mechanisms and knowledge of their functions is fundamental for understanding the pathophysiology of autoimmune diseases and to subsidize the strategies of interference in the mechanisms of recovery of tolerance in these pathologies. The need to review basic knowledge about $\mathrm{CD} 4^{+} \mathrm{CD} 25^{+}$ $\mathrm{T}$ cells, their role in different rheumatic diseases, and the prospects of advancement in the treatment of autoimmune diseases through the manipulation of these cells is therefore justified.

Naturally occurring $T$ cells are related to the maintenance of self-tolerance and are very important for the maintenance of homeostasis of the immune system. ${ }^{16} \mathrm{~T}_{\text {regs }}$ are involved in the inhibition of the activation and expansion of autoreactive lymphocytes in the peripheral tissues and present an inhibitory capacity with a proven role in the negative regulation of the immune response also against exogenous antigens and autoantigens. ${ }^{17-19}$ Currently, $\mathrm{T}_{\text {regs }}$ have been investigated for their role in the immunomodulation of responses in inflammatory, neoplastic, autoimmune syndromes and also in transplant rejection, in the hope of opening other therapeutic perspectives to control exacerbated immune responses without the induction of anergy or nonresponsiveness, but by activating cellular function. ${ }^{20-23}$ Early reports on cell subtypes specialized in regulating the immune response occurred in the 1970s, when it was shown that some subtypes of $\mathrm{T}$ lymphocytes were able to suppress the development of autoimmune diseases. ${ }^{24}$ Later, other authors ${ }^{1,15}$ demonstrated the constitutive labeling of the $\alpha$-chain receptor of IL-2 (CD25) by $\mathrm{CD} 4^{+} \mathrm{T}$ lymphocytes and attributed to it a role in the suppression of autoimmune diseases in mice. Proof of this role was possible by the removal of $\mathrm{CD} 25^{+}$splenocytes in healthy rodents, triggering autoimmune disorders such as thyroiditis, insulinitis, polyarthritis, glomerulonephritis, and graft versus host disease. It was also demonstrated that adoptive transfer of this population inhibited autoimmunity in experimental models. ${ }^{15,25}$

Interest in the study of $\mathrm{T}_{\text {regs }}$ is due to the key function of this cellular population in the maintenance of the mechanisms of self-tolerance and in the regulation of the immune response..$^{20} \mathrm{CD} 4{ }^{+} \mathrm{CD} 25^{+} \mathrm{T}$ lymphocytes represent 5 to $10 \%$ of total $\mathrm{CD}^{+}$cells in peripheral blood..$^{25-27}$ Evidence obtained in later studies shows that $\mathrm{CD} 4^{+} \mathrm{CD} 25^{+}$thymocytes are selected in the thymus from interactions with proper peptides presented by MHC-II molecules. ${ }^{27}$ Positive selection of these cells depends on high-affinity interactions with autoantigens expressed on MHC molecules. ${ }^{28}$ The mechanism by which $\mathrm{CD} 4^{+} \mathrm{CD} 25^{+} \mathrm{T}$ cells escape negative selection is still controversial, but it is believed that these, once positively selected through high affinity recognition of their own peptides, produce anti-apoptotic molecules that protect them from negative selection. ${ }^{29}$ $\mathrm{T}_{\text {reg }}$ cells, besides the thymic generation, can be induced in the periphery by the action of specific soluble factors on naive cells that have just left the thymus.

Annunziato et al..$^{30}$ evaluated phenotypic and functional characteristics of human thymus cells and have demonstrated that these cells respond to chemotactic signals from macrophages and epithelial cells constitutive of the thymus itself, and that are capable of expressing $\mathrm{CD}^{+}, \mathrm{CD} 25^{+}$and mTGF- $\beta 1$, as well as molecules directly with immunosuppressive function, such as CTLA-4. These cells had low production of IL-10 and none of IL-2, IL-4, IL-5, IL-13 and IFN-U..$^{30,31}$ In addition to thymus, human $\mathrm{T}_{\text {reg }}$ cells were isolated in other microenvironments, such as secondary lymphoid organs, e.g., tonsils and spleen, as well as umbilical cord blood. ${ }^{1}$ Also, $\mathrm{CD} 4^{+} \mathrm{CD} 25^{+} \mathrm{T}$ cells 
present in the thymus have been reported as naïve cells that become activated and express a memory phenotype when they exit toward the periphery. ${ }^{32}$

Studies by Sakaguchi et al. ${ }^{15,16}$ had already characterized the T-cell phenotype based only on the constitutive expression of the CD4 and CD25 markers, although it is known that any other $\mathrm{CD} 4^{+} \mathrm{CD} 25^{\circ}$ cell may, after being activated, begin to transiently express the CD25 molecule. In humans, $\mathrm{CD} 4^{+} \mathrm{T}$ cells have differentiated profiles of CD25 receptor expression, with differentiated intensities detected in the medium channel of fluorescence, so that it is possible to identify, in the "gate" in $\mathrm{CD} 4^{+} \mathrm{CD} 25^{+}$cells, a more abundant population, expressing low levels of $\mathrm{CD} 25$, and a lower percentage of CD4, with high intensity of expression of this receptor. ${ }^{27,33}$ This last population, with intense expression of $\mathrm{CD} 25$, corresponds to the pool of this subpopulation. However, there is limitation of the $\mathrm{CD} 25$ receptor as a $\mathrm{T}_{\mathrm{reg}}{ }^{20}$ phenotypic marker. The current strategy for isolation and characterization of $\mathrm{T}_{\text {regs }}$ is based on the recognition of this marker. CD25 also represents, in the physiology of this cell, an indispensable component for its generation and maintenance in the organism.

As previously mentioned, regarding the biomolecular approach, researchers ${ }^{6,15}$ have demonstrated that transcription factor Foxp 3 is predominantly expressed by thymic and peripheral $\mathrm{T}_{\text {regg }}{ }^{6}, 15$ Naive $\mathrm{T}$ cells transfected with Foxp3 mRNA acquire characteristic of regulatory cells becoming anergic and suppressive in vitro. It was further observed that the transfected cells acquired $\mathrm{T}_{\text {reg }}$-like phenotype in relation to phenotypic expression and the production of cytokines and other T-related molecules such as CD25, CTLA-4, CD103 and GITR. Transfected cells also have the ability to suppress the proliferation of other $\mathrm{T}$ cells and to inhibit the development of autoimmune disease and inflammatory vessel disease in vivo. ${ }^{6,34}$ It has also been shown that the number of $\mathrm{T}_{\text {regs }}$ is increased in mice transgenic to Foxp3 and that mice KO for this gene show hyperactivation of $\mathrm{T}$ cells. According to previous reports, ${ }^{6,15}$ Foxp3 appears to be a very important gene in the development and function of $\mathrm{CD} 4^{+} \mathrm{CD} 25^{+} \mathrm{T}$ cells, both in mice and humans.

Patients with Foxp 3 mutation have been shown to develop IPEX syndrome (immune dysregulation, polyendocrinopathy, enteropathy, X-linked syndrome). This condition consists of an autoimmune disorder that affects multiple organs with development of allergy and inflammatory vessel disease. These patients appear to be impaired in terms of the development of $\mathrm{T}_{\text {regs }}$, thus presenting defective suppression function, which induces a state of hyperactivation of $\mathrm{T}$ cells that become reactive against autoantigens, commensal bacteria of the intestine or innocuous environmental antigens..$^{20}$ Most $\mathrm{T}$ cells expressing Foxp 3 are $\mathrm{CD} 4^{+} \mathrm{CD} 25^{\text {thigh }}$ and $\mathrm{CD} 4^{+} \mathrm{CD} 25^{\text {tlow }}$, that is, cells with high expression of CD25 and cells with low expression of CD25 that are capable of suppressing $\mathrm{T}$ cell proliferation with the same intensity.

Later, Seddiki et al..$^{35}$ demonstrated that anti-CD127 monoclonal antigen is able to clearly mark the population of $\mathrm{T}_{\text {regs }}$, with suppressive activity. Previous studies have reported that Foxp3 expression did not always correlate with the expression of the CD25 molecule. ${ }^{36}$ Liu et al. ${ }^{37}$ found that most $\mathrm{CD} 4^{+} \mathrm{Foxp}^{+}$cells were $\mathrm{CD} 25^{\text {high }} \mathrm{CD} 127^{\text {low }}$. This study demonstrated that CD25CD127 labeling was able to accurately indicate a population of suppressor $\mathrm{T}$ cells with a higher degree of purity, leading to the assumption that $\mathrm{CD} 4^{+} \mathrm{T}$ cells could actually be significantly higher than previously thought. Thus, it is possible to distinguish clearly from a population of $\mathrm{T}$ cells the newly activated effector cells and memory cells, since only newly activated $\mathrm{T}$ cells have constitutively low expression of CD127, whereas memory cells have high expression of this marker and the traditional effector cells rapidly reexpress this marker upon activation. ${ }^{35-37}$ In addition, the use of other markers such as CTLA-4 and CD122, although also expressed under activation conditions, may aid in their characterization. In autoimmune disorders such as rheumatoid arthritis (RA), there is a lot of evidence that the breakdown of immune tolerance mechanisms begins in the thymus with the escape of clones with self-reactive potential. In our preliminary studies, we demonstrated that the majority of the peripheral blood samples from RA patients who were evaluated had the HLA-DR marker. It is known that certain HLA-DR alleles determine both the susceptibility to the disease and its severity. These determinants, and perhaps others of a genetic nature, may be susceptible to an unidentified environmental factor. Nevertheless, progression or not to autoimmunity appears to be critically and relevantly determined in the periphery. Most often, tolerance mechanisms can control the peripheral activation of autoreactive clones that are eliminated or anergized. When this control is insufficient, autoimmune disease manifests itself.

$\mathrm{T}_{\text {reg }}$ cells are responsible for the maintenance of "active" mechanisms of suppression and immunoregulation that work together with the other mechanisms of peripheral tolerance. Several studies have been carried out, evaluating the role of $\mathrm{T}$ cells in the maintenance of peripheral tolerance and the pathophysiology of autoimmune diseases. Its relevance in this process has been clearly demonstrated in murine models in which the absence or depletion 
of $\mathrm{T}$ cells triggers systemic autoimmune diseases with high titers of antinuclear antibodies as well as autologous organ-specific antibodies. ${ }^{15}$ Important findings, such as defects in function, phenotype and frequency of immunoregulatory cells, have been reported in several human autoimmune rheumatic diseases, thus evidencing their important role in maintaining immunological tolerance and in the pathophysiological mechanisms of these diseases. The proportion of $\mathrm{T}_{\text {reg }}$ cells in peripheral blood was related to the observation of increased levels in peripheral blood and synovial fluid, in addition to the demonstration of suppressive activity more powerful than that observed in the peripheral ones. ${ }^{38-40}$ In contrast, normal levels of $\mathrm{T}_{\text {reg }}$ in peripheral blood were also detected in some studies. This variability probably stems from differences in disease stage, therapy and certainly variations in the strategies for characterization of RAs.

In more recent research, Cao et al. ${ }^{41,42}$ found that in approximately $95 \%$ of patients with rheumatic diseases that progress with arthritis, such as: RA, juvenile rheumatoid arthritis, ankylosing spondylitis, systemic lupus erythematosus (SLE), Behcet's disease, rheumatic polymyalgia and mixed connective tissue disease, all presenting high levels of $\mathrm{T}_{\text {regs }}$ in the inflamed joint, despite the clinical condition and disease time. ${ }^{41,42}$ These authors suggest that $\mathrm{T}_{\text {regs }}$, even if numerically enhanced in inflamed synovium and with normal suppressor function, are unable to suppress secretion of proinflammatory cytokines by activated $\mathrm{T}$ cells or monocytes. This may occur because the suppressive action of $\mathrm{T}$ lymphocytes would be overcome by other lymphocytes with strong activation signals present at these sites, including Th1 and Th17 cells. ${ }^{43}$ This fact is in accordance with the data presented by Nistala et al., ${ }^{44}$ who demonstrated that the balance between the populations of $\mathrm{T}_{\text {regs }}$ and Th17 is inversely correlated and very important in the progression of the disease. ${ }^{44}$ Failure of the $\mathrm{T}_{\text {regs }}$ in RA was also suggested by Van Amelsfort et al. ${ }^{45}$ who reported levels and suppressive activity of this increased cellular subtype in synovium of RA patients compared to the same peripheral blood population. However, inflammation persisted. Monocyte-derived cytokines, such as TNF and IL-7, as well as co-stimulatory molecules such as $\mathrm{CD} 28$, are possibly counteracting factors in the suppression of $\mathrm{T}_{\text {regs }}$ in these patients, both in synovial fluid and in peripheral blood, preventing suppression. ${ }^{45}$

\section{INTERLEUKIN 10 (IL-10) IN AUTOIMMUNE AND IDIOPATHIC DISEASES}

In earlier preliminary studies, the authors observed that in myasthenia gravis (MG), an autoimmune disorder, there is an increase in $\mathrm{T}_{\mathrm{reg}}$ cells in the blood of individuals not treated with corticosteroids, and a decrease in $\mathrm{CD}^{+}$ $\mathrm{T}$ cells. The population of $\mathrm{CD} 4^{+} \mathrm{IL}-10^{+} \mathrm{T}$ cells obtained by Ficoll gradient separation and fluorescently labeled with monoclonal antibodies was significantly increased, with a significant reduction of clinical symptoms. In this case, IL-10 in association with CD25 appears to exert peripheral tolerance control. Studies by Falcão et al ${ }^{46}$ had already demonstrated a role of this cytokine in controlling exacerbated responses in infectious-parasitic diseases. In schistosomiasis mansoni, asymptomatic patients have a high IL-10 profile, together with other molecules such as HLA-DR and other co-stimulatory molecules. However, in another study, the authors reported that $\mathrm{T}_{\text {regs }}$ did not significantly express INF- $\gamma$ and inhibition of $\mathrm{T}$ cell proliferation was not achieved. Studies have shown that IL-10 inhibits APC activation and is related to inflammatory control reactions in target tissues. ${ }^{47}$

In $\mathrm{MG}$, a disease that attacks the postsynaptic portion of the neuromuscular junction and is characterized by fluctuating muscle weakness, the biological heterogeneity investigated for the first time when rabbits with acetylcholine receptors were purified to obtain antibodies against that receptor has been demonstrated. Immunized rabbits had fallen ears and palpebral ptosis (drooping eyelid) with improvement at rest and worsening with exercise, infections and emotional stress. ${ }^{48}$ The role of these antibodies in the etiology of MG was clearly established in the 1970s, when plasmapheresis proved to be effective in the removal of antibodies and consequent functional improvement for more than 2 months. ${ }^{49,50}$ Well-established anatomical changes were also observed, including increased neuromuscular junction size and decreased post-synaptic membrane length. Other important observations have been reported on the role of autologous antibodies in MG, since approximately $50 \%$ of patients with the disease without $A c h$ anti-receptor antibodies have antibodies against a muscle membrane enzyme called muscle-specific tyrosine kinase (anti-Musk). Lavrnic et al. ${ }^{48}$ analyzed 17 patients with this condition, observing a higher prevalence of women, predominant facial and bulbar involvement and refractoriness to anticholinesterase compounds. Because it is an autoimmune disease, other conditions of the same nature may coexist in a patient with a diagnosis of MG, and should be screened rationally, especially hypothyroidism, hyperthyroidism and thymus disease. ${ }^{50}$ Seventy percent $(70 \%)$ of patients have thymic hyperplasia and approximately $10 \%$ have thymoma - with potential for malignant behavior, which is more common in patients aged 50-70 years. 
As previously mentioned, patients with clinically controlled RA had an increased $\mathrm{T}_{\text {reg }}$ profile; however, the authors found a differential expression of receptors on the surface of peripheral blood lymphocytes from individuals with a diagnosis of MG, with a symptom of muscle weakness, and who were treated with prednisone and azathioprine, which are immunosuppressive agents. They showed a decreased profile of $\mathrm{T}_{\text {regs }}$ and $\mathrm{CD} 4^{+} \mathrm{IL}-10$, as well as increased CD $8^{+} \mathrm{CTLA}-4^{+} \mathrm{T}$ cells. ${ }^{51}$

As a consequence of previous studies, ${ }^{52}$ the authors also reported the role of these two receptors in idiopathic diseases, such as Bell's palsy. Patients with autologous induction of IL-10, obtained through receptor purification, have been shown to have clinical improvement as well as increased $\mathrm{T}_{\text {reg }}$ expression. $\mathrm{CD} 4^{+} \mathrm{T}$ lymphocytes were found to present increased expression after one week of induction. Paralysis affects the facial nerve (cranial nerve VII), which results in inability to control the facial muscles on the affected side. Several other conditions can also cause facial paralysis, for example, brain tumor, stroke and Lyme disease. A person may experience pain behind the ear a few hours before muscle weakness occurs. Clinical treatment includes prescribing anti-inflammatory drugs such as prednisone. Also, as in MG, immunosuppressive treatment has been used and is effective in controlling symptoms and reducing exacerbations. Pyridostigmine is reserved for refractory cases. The different dosages of glucocorticoid (daily use, alternating use or pulse therapy) do not seem to yield different efficacies. ${ }^{53-55}$ The receptor-glucocorticoid complex enters the cell nucleus and causes some changes in the DNA that stimulate or repress the synthesis of certain tissue proteins. Prednisone is particularly effective as an immunosuppressant and alters the performance of the immune system, with a decrease in mediators for inflammation. This decrease, in certain cases, prevents the communication with other cells of the immune system that should be recruited in order to modulate the inflammatory process through the production of physiological proteins, such as interleukin 10 (IL-10). Prednisone is used in autoimmune and inflammatory diseases and, at a given moment, induces immunological immunosuppression states, precisely because it prevents the receptors fixed on the surface of the defense cells and soluble cofactors from playing their roles in cellular activation, considering that the analogous receptors of the drug can share the same ligands of IL-10, preventing its action. Prednisone is biotransformed in the liver into prednisolone by the action of the enzyme dehydrogenase 11-beta-hydroxysteroid type 1. From 1 to 3 hours after administration, the drug reaches plasma peaks.
Its plasma half-life is approximately 3 hours, its biological half-life thus being 12 to 36 hours in this case. ${ }^{56}$

Receptors are surface proteins that bind to external signaling molecules of high affinity cells and convert this extracellular event into one or more intracellular signals that alter the behavior of the target cell. Note that the receptors for IL-10 are arranged as two-chain $\alpha$-tetramers (IL-10 receptor $\alpha$-chain) and two $\beta$-chains (IL-10 receptor $\beta$-chain) (Figure 2). Signaling occurs through interaction with Janus kinases. IL-10 belongs to these two receptor chains, which associate the Jak-1 and Tyk-2 kinases of the Janus family. STAT-3 is the main "downstream" signaling molecule induced by IL-10, which is produced mainly by regulatory $\mathrm{T}$ cells but also by macrophages and keratinocytes present in epithelial tissue. ${ }^{1}$ STAT-3 is expected to act to inhibit gene transcription of inflammatory and/or autoreactive receptors, forming the STAT complex in association with Jak-1 and Tyk-2, with consequent nuclear translocation and gene activation, since mRNA of these enzymes were detected by RT-PCR, with bands of around $120 \mathrm{KDa}$, with anti-janus-kinase1. The high expression of $\mathrm{CD} 4^{+} \mathrm{CD} 25^{\text {tow }}$ and $\mathrm{CD} 4^{+} \mathrm{IL}-10^{+}$high $\mathrm{T}$ cells found after induction of autologous IL-10 can be explained by occupying both R1 and R2 IL-10 receptors. Also, in many cases, the generation of autoreactive antibodies or $T$ cells can also be attributed to the role played by infectious agents present in the body of the individual, such as bacteria, which lead to the generation of antibodies and $\mathrm{T}$ cells which, in turn, react with many different epitopes of the infectious organism. If one of these antigens is similar to an autoantigen it may result in an autoimmune response. ${ }^{52}$

Ex vivo monitoring of IL-10 can be obtained by analysis of human peripheral blood mononuclear cells, grown in vitro and induced by blastogenesis for the production of proteins (interleukins), through mitogenic stimulation with PHA (phytohemagglutinin). Protocols developed for in vitro and in vivo experimental phase were filed with patent application PI0206722-6, supported by experiments with animal models highly homologous to the human genome..$^{52}$ The protein fraction of IL-10 obtained by PCR and purified, free of contaminants can be analyzed by electrophoresis and quantified by UV-visible spectrometry. The procedure may become a routine.

Falcão et al. ${ }^{52}$ demonstrated that IL-10 suspensions, ex vivo, can be applied at the inflammatory site, connective tissue and muscle. In cases of syndromes that render the synapses between first-order neurons in the periphery unfeasible, the application was close to the areas of muscle, subcutaneous or intradermal flaccidity. ${ }^{52}$ Assuming a regular interval of 10 days between applications, the monitoring 


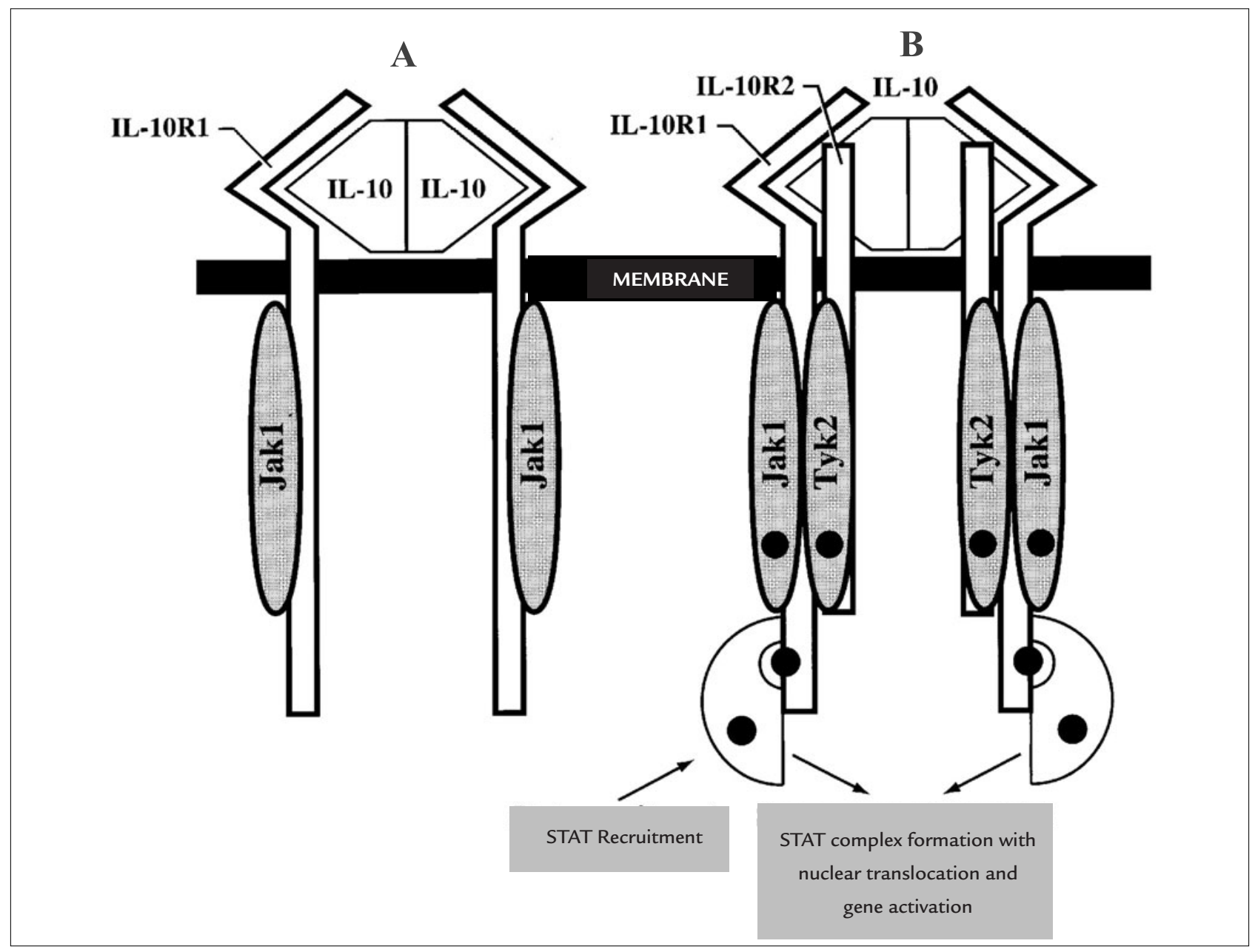

FIGURE 2 IL-10 receptor binding via STAT-3. A. Binding of IL-10 to IL-10R1 receptor via receptor-anchored Jak-1 kinase. B. Binding of IL-10 to IL-10R2 receptor, recruitment of STAT-3 and STAT complex formation and gene activation by Jak-1 and Tyk-2 kinases. Both "outside-in" and "inside-out" signaling are associated with distinct conformational changes in the extracellular segment. These changes vary with the type and nature of the ligand and are modulated by divalent cations. (Adapted from Abbas and Lichtman, ${ }^{1} 2005$. )

of the modulation of the inflammatory profile was performed according to Falcão et al. ${ }^{52}$ The receptors were identified by flow cytometry, and their fluorescent histograms were prepared so that the absolute number of cell surface receptors labeled with the anti-receptor fluorescent monoclonal antibody of interest was generated, or the mRNAs for genes of the receptors were detected. As a result, they found an increase in the production of $\mathrm{T}_{\text {regs, }}, \mathrm{CD} 4^{+} \mathrm{HLA}-\mathrm{DR}^{+}$, a decrease in $\mathrm{CD}^{+}{ }^{+} \mathrm{CTLA}-4^{+}$and an increase in the expression of IL-10 by $\mathrm{T}_{\text {regs }}$ up to the fourth week, with a mean of the absolute number of receptors maintained after the sixth week. The expression of CD8 ${ }^{+} \mathrm{INF}-\gamma^{+}$and $\mathrm{CD} 14^{+} \mathrm{INF}-\gamma^{+}$was markedly decreased in the samples evaluated. ${ }^{52}$

Thus, it is conclusive that the monitoring and manipulation of proinflammatory interleukins has the potential to assist in the prognosis of anti and pro-inflam- matory and degenerative changes in situ, monitoring the course of the disease.

\section{SYNTHESIS OF TRACERS FOR IN VIVO MONITORING}

Image monitoring of symptoms of autoimmune diseases, such as RA, is preferable considering that such a technique will directly contribute to the accuracy of the diagnosis and consequently the establishment of the therapeutic mode and its intensity. ${ }^{57}$ The accurate definition of the site with a design of the inflammatory focus is relevant in the choice of therapeutic management in RA. ${ }^{58}$ Radiological imaging, radiography, computed tomography, nuclear magnetic resonance or ultrasound may favor an analysis of the deleterious effects on the anatomical structures in the peripheral joints. ${ }^{59}$ However, such images do not aid in the early analysis of RA. Scintigraphy, on the 
other hand, may promote an early diagnosis of inflammatory processes by monitoring the early stages of inflammation. Thus, radioisotope scintigraphy is expected to contribute to the diagnosis of RA by monitoring functional and physiological changes at the inflamed site before anatomical structural changes consequent to RA can become apparent. ${ }^{60}$

Positron-emitting fluoride-18-labeled deoxy-glucose (FDG) is a radiopharmaceutical used in positron emission (PET) scintigraphy. The compound accumulates in the inflammatory site, given the high local metabolism. The high supply of leukocytes in the inflamed site leads to increased glucose consumption. ${ }^{61}$ However, due to the high cost of production of this 110 -minute half-life radiopharmaceutical, together with the cost of PET imaging, it is currently impracticable to perform systematic clinical studies of RA using this technique. Cost reduction or new methods and radiopharmaceuticals should be produced to enable scintigraphy of RA. ${ }^{61}$ The use of radiolabeled ex-vivo leukocytes is attractive; however, they involve difficult management with high control of sterility and apyrogenicity. ${ }^{62}$ Although leukocyte scintigraphy radiolabeled with ${ }^{111} \mathrm{In}$ and ${ }^{99 \mathrm{~m}} \mathrm{Tc}$ is a gold standard for the diagnosis of inflammation, the process of marking autologous leukocytes with ${ }^{99} \mathrm{~m}$ Tc-HMPAO demands manipulation of blood samples in aseptic facilities with the reintroduction of these samples into the patient. ${ }^{63}$ Obviously, there is the inherent risk of contamination, during manipulation of PBMC cells and isolation and labeling of leukocytes. ${ }^{63}$

A recent patent PI0904754-9, developed by the research group coordinated by the author, has shown that Tc-99m-labeled thio-sugar analogues of glucose are efficient in detecting inflammations. ${ }^{64}$ Previous synthesis studies had been successfully performed using 5-thio-Dglucose; however, due to cost issues, there was a need to replace the thio-sugar molecule. ${ }^{65}$ The importance of thio-sugars in inflammations was demonstrated in the temporomandibular joint (TMJ) of rats. ${ }^{63}$ The patent involves 5-thio-glucose and 1-beta-thio-D-glucose labeled with Tc- $99 \mathrm{~m} .{ }^{64}$ The results show significant differences in the uptake of ${ }^{99 \mathrm{~m}} \mathrm{Tc}-1-\mathrm{TG}$ in the inflamed TM joint compared to the control, with high renal excretion. Tc-99m-labeled glucose analogs may become radiopharmaceuticals important for detection in the monitoring of inflammations such as AR due to the low cost and high technological feasibility. However, despite the murine investigations, there is still a need for clinical investigations demonstrating its efficiency in the early detection of RA and the degree of disease involvement in humans before and after immunological treatment.
Research on the synthesis and characterization of sugars with heavy metals has advanced. Recently, Dalmazio and Campos ${ }^{66}$ demonstrated by mass spectrometry the viability of direct labeling of sugar polymolecules with Sm, Gd, B, Li, $\mathrm{Tc}, \mathrm{Sm}, \mathrm{Ho}, \mathrm{Eu}$, and other elements. These metal-sugar complexes make it possible to define several tracers for different modalities of medical imaging tests. These studies lack in vivo experimentation, but already offer a promising perspective in the monitoring of autoimmune diseases.

IL-1 and IL-6 interleukins play a crucial role in RA and osteoarthritis in the early processes of cartilage breakdown and destruction. ${ }^{65}$ A significant increase of IL- 6 in patients with osteoarthritis was identified by Kaneyama et al ${ }^{67}$ In 2014, in turn, Sukedai et al ${ }^{68}$ report the relation between TNF- $\alpha$ and cartilage degeneration. These authors show that IL-8 is closely involved with the acute phase of the inflammatory process. Thus, interleukins, such as IL-1, IL-6, IL-8, are proteins with which in vivo monitoring may lead to differential diagnosis of RAs.

Radiolabeled sugars serve the monitoring of inflammation induced by autoimmune diseases; however, they are not specific. It is worth saying that the interleukins themselves have high potential for radiolabeling. Rennen et al. ${ }^{61,69}$ performed the labeling of IL- 8 with Tc- $99 \mathrm{~m}$ making it possible to diagnose inflammation through radiolabeled interleukins. ${ }^{69}$ Thus, we conclude that inflammatory cytokines are potential markers to aid in the diagnosis and prognosis of anti- and pro-inflammatory and degenerative changes in situ, monitoring the course of the disease. Radiolabeled cytokines, together with high metabolism labeling radiopharmaceuticals, represent a promising class of compounds for the evaluation of autoimmune diseases, since these proteins play an important role in inducing and maintaining the disease process.

\section{Conclusion}

The present review addressed cellular markers whose analysis and modulation may be useful in the treatment of autoimmune and idiopathic diseases, as well as in the prognostic monitoring of diseases. It has been noted that the ex-vivo monitoring and manipulation of interleukin IL-10 is relevant for treatment, and that thio-sugars, monossacharides, polysaccharides and radiolabeled interleukins are tools for in vivo monitoring of autoimmune and idiopathic diseases. Future consolidation of scintigraphic methods can help monitor the progression of such diseases. Advances in research on modulation and generation of radioactive drugs involving cell markers for diagnosis and therapy may bring benefits to patients with autoimmune diseases. 


\section{Resumo}

O papel de células T regulatórias, da interleucina 10 e da cintilografica in vivo em doenças autoimunes e idiopáticas - Perspectivas terapêuticas e prognóstico

Estudos anteriores já haviam demonstrado a expressão do marcador CD25 na superfície de células $\mathrm{T}$ de ocorrência natural $\left(T_{\text {regs }}\right)$ de camundongos, que apresentam perfil celular autorreativo. Recentemente, foi detectada, em subtipos de linfócitos de indivíduos acometidos por doenças autoimunes e de causa idiopática, a expressão de outros marcadores, que auxiliam na identificação dessas células, entre os quais: CD25, CTLA-4 (cytotoxic T-lymphocyte antigen 4), HLA-DR (buman leucocyte antigen) e Interleucina 10 (IL-10), abrindo novas perspectivas para a melhor compreensão de uma associação entre esses receptores presentes na superfície celular e o prognóstico de doenças autoimunes. $\mathrm{O}$ papel dessas moléculas já havia sido descrito na literatura na modulação da resposta inflamatória em doenças infectoparasitárias. Dessa forma, foram investigados a função, o fenótipo e a frequência de expressão, do receptor de cadeia $\alpha$ da IL-2 (CD25) e de IL-10 em subtipos de linfócitos. O modelo murino tem sido utilizado para demonstrar uma possível correlação entre a expressão do marcador CD25 (na superfície de linfócitos CD4) e o controle dos mecanismos de autotolerância. Essas pesquisas forneceram suporte para apresentação de uma revisão sobre o papel das células que expressam os receptores de IL-2, IL-10, HLA-DR e CTLA-4 no monitoramento da imunossupressão, em doenças de classificação autoimune, abrindo perspectivas para o entendimento dos mecanismos de regulação periférica e sobre a fisiopatologia dessas doenças no ser humano. Além disso, é discutida como perspectiva uma abordagem terapêutica fundamentada na manipulação do fenótipo dessas células, bem como de modos de monitoramento cintilográfico das manifestações dessas doenças, por meio da marcação de seus receptores. Nestes, foram incluídas descrições das experiências em regulação ex-vivo de IL-10; de síntese de tioaçúcares e de poliaçúcares para produção de radiofármacos para monitoramento de inflamações. Essas experiências podem trazer benefícios na terapia e no prognóstico de doenças autoimunes.

Palavras-chave: células $\mathrm{T}_{\text {regs }}$, IL-10, autoimunidade, idiopatias, cintilografia.

\section{REFERENCES}

1. Abbas AK, Lichtman AH. Cellular and molecular immunology. 5. ed. Philadelphia: Saunders; 2005. p. 225-43.
2. Lippolis JD. Immunological signaling networks: integrating the body's immune response. J Anim Sci. 2008; 86(14 Suppl):E53-63

3. Janeway CA Jr. How the immune system protects the host from infection. Microbes Infect. 2001;3(13):1167-71.

4. Kappler JW, Roehm N, Marrack P. T cell tolerance by clonal elimination in the thymus. Cell. 1987; 49(2):273-80.

5. Burns J, Rosenzweig A, Zweiman B, Lisak RP. Isolation of myelin basic protein-reactive T-cell lines from normal human blood. Cell Immunol. 1983; 81(2):435-40

6. Campbell DJ, Ziegler SF. FOXP3 modifies the phenotypic and functional properties of regulatory T cells. Nat Rev Immunol. 2007; 7(4):305-10.

7. Jiang H, Chess L. An integrated view of suppressor $\mathrm{T}$ cell subsets in immunoregulation. J Clin Invest. 2004; 114(9):1198-208.

8. Papiernik M, Carmo Leite-de-Moraes M, Pontoux C, Joret AM, Rocha B, Penit $\mathrm{C}$, et al. $\mathrm{T}$ cell deletion induced by chronic infection with mouse mammary tumor virus spares a CD25-positive, IL-10-producing T cell population with infectious capacity. J Immunol. 1997; 158(10):4642-53.

9. Bach JF. Organ-specific autoimmunity. Immunol Today. 1995; 16(7):353-5.

10. Pearson CI, McDevitt HO. Redirecting Th1 and Th2 responses in autoimmune disease. Curr Top Microbiol Immunol. 1999; 238:79-122.

11. Sharif S, Arreaza GA, Zucker P, Mi QS, Delovitch TL. Regulation of autoimmune disease by natural killer T cells. J Mol Med (Berl). 2002; 80(5):290-300.

12. Hayday A, Tigelaar R. Immunoregulation in the tissues by gammadelta $T$ cells. Nat Rev Immunol. 2003; 3(3):233-42.

13. Ni Choileain N, Redmond HP. Regulatory T-cells and autoimmunity. J Surg Res. 2006; 130(1):124-35.

14. Lu L, Werneck MB, Cantor H. The immunoregulatory effects of Qa-1. Immunol Rev. 2006; 212:51-9.

15. Sakaguchi S, Sakaguchi N, Asano M, Itoh M, Toda M. Immunologic selftolerance maintained by activated T cells expressing IL-2 receptor alphachains (CD25). Breakdown of a single mechanism of self-tolerance causes various autoimmune diseases. J Immunol. 1995; 155(3):1151-64.

16. Sakaguchi S. Regulatory T cells: key controllers of immunologic self-tolerance. Cell. 2000; 101(5):455-8.

17. Sakaguchi S. Naturally arising CD4+ regulatory T cells for immunologic self-tolerance and negative control of immune responses. Annu Rev Immunol. $2004 ; 22: 531-62$

18. Von Boehmer H. Mechanisms of suppression by suppressor T cells. Nat Immunol. 2005; 6(4):338-44.

19. Baecher-Allan CM, Hafler DA. Functional analysis of highly defined, FACS isolated populations of human regulatory CD4+CD25+ T cells. Clin Immunol. 2005; 117(2):192; discussion 193.

20. Shevach EM. Regulatory T cells in autoimmunity. Annu Rev Immunol. 2000; 18:423-49.

21. Afzali B, Lombardi G, Lechler RI, Lord GM. The role of T helper 17 (Th17) and regulatory $\mathrm{T}$ cells (Treg) in human organ transplantation and autoimmune disease. Clin Exp Immunol. 2007; 148(1):32-46.

22. Demengeot J, Zelenay S, Moraes-Fontes MF, Caramalho I, Coutinho A Regulatory $\mathrm{T}$ cells in microbial infection. Springer Semin Immunopathol. 2006; 28(1):41-50.

23. Khazaie K, von Boehmer H. The impact of CD4+CD25+ Treg on tumor specific CD8+ T cell cytotoxicity and cancer. Semin Cancer Biol. 2006; 16(2):124-36

24. Gershon RK, Kondo K. Cell interactions in the induction of tolerance: the role of thymic lymphocytes. Immunology. 1970; 18(5):723-37.

25. Sakaguchi S, Fukuma K, Kuribayashi K, Masuda T. Organ-specific autoimmune diseases induced in mice by elimination of $\mathrm{T}$ cell subset. I Evidence for the active participation of T cells in natural self-tolerance; deficit of a T cell subset as a possible cause of autoimmune disease. J Exp Med. 1985; 161(1):72-87.

26. Fehérvari Z, Sakaguchi S. CD4+ Tregs and immune control. J Clin Invest. 2004; 114(9):1209-17.

27. Baecher-Allan C, Brown JA, Freeman GJ, Hafler DA. CD4+CD25high regulatory cells in human peripheral blood. J Immunol. 2001; 167(3):1245-53.

28. Jordan MS, Boesteanu A, Reed AJ, Petrone AL, Holenbeck AE, Lerman MA, et al. Thymic selection of CD4+CD25+ regulatory T cells induced by an agonist self-peptide. Nat Immunol. 2001; 2(4):301-6.

29. Maggi E, Cosmi L, Liotta F, Romagnani P, Romagnani S, Annunziato F. Thymic regulatory T cells. Autoimmun Rev. 2005; 4(8):579-86.

30. Annunziato F, Cosmi L, Liotta F, Lazzeri E, Manetti R, Vanini V, et al. Phenotype, localization, and mechanism of suppression of CD4(+)CD25(+) human thymocytes. J Exp Med. 2002; 196(3):379-87. 
31. Taams LS, Smith J, Rustin MH, Salmon M, Poulter LW, Akbar AN. Human anergic/suppressive CD4(+)CD25(+) T cells: a highly differentiated and apoptosis-prone population. Eur J Immunol. 2001; 31(4):1122-31.

32. Wing K, Ekmark A, Karlsson H, Rudin A, Suri-Payer E. Characterization of human CD25+ CD4+ T cells in thymus, cord and adult blood. Immunology. 2002; 106(2):190-9.

33. Levings MK, Sangregorio R, Sartirana C, Moschin AL, Battaglia M, Orban PC, et al. Human CD25+CD4+ T suppressor cell clones produce transforming growth factor beta, but not interleukin 10, and are distinct from type $1 \mathrm{~T}$ regulatory cells. J Exp Med. 2002; 196(10):1335-46.

34. Fontenot JD, Gavin MA, Rudensky AY. Foxp3 programs the development and function of CD4+CD25+ regulatory T cells. Nat Immunol. 2003; 4(4):330-6.

35. Seddiki N, Santner-Nanan B, Martinson J, Zaunders J, Sasson S, Landay A, et.al. Expression of interleukin (IL)-2 and IL-7 receptors discriminates between human regulatory and activated T cells. J Exp Med. 2006; 203(7):1693-700

36. Fontenot JD, Rasmussen JP, Williams LM, Dooley JL, Farr AG, Rudensky AY. Regulatory $T$ cell lineage specification by the forkhead transcription factor foxp3. Immunity. 2005; 22(3):329-41.

37. Liu W, Putnam AL, Xu-Yu Z, Szot GL, Lee MR, Zhu S, et al. CD127 expression inversely correlates with FoxP3 and suppressive function of human CD4+ T reg cells. J Exp Med. 2006; 203(7):1701-11.

38. Möttönen M, Heikkinen J, Mustonen L, Isomäki P, Luukkainen R, Lassila O. CD4+ CD25+ T cells with the phenotypic and functional characteristics of regulatory $\mathrm{T}$ cells are enriched in the synovial fluid of patients with rheumatoid arthritis. Clin Exp Immunol. 2005; 140(2):360-7.

39. van Amelsfort JM, Jacobs KM, Bijlsma JW, Lafeber FP, Taams LS. CD4(+) $\mathrm{CD} 25(+)$ regulatory $\mathrm{T}$ cells in rheumatoid arthritis: differences in the presence, phenotype, and function between peripheral blood and synovial fluid. Arthritis Rheum. 2004; 50(9):2775-85.

40. Cao D, Malmström V, Baecher-Allan C, Hafler D, Klareskog L, Trollmo C. Isolation and functional characterization of regulatory CD25brightCD4+ $\mathrm{T}$ cells from the target organ of patients with rheumatoid arthritis. Eur J Immunol. 2003; 33(1):215-23.

41. Cao D, van Vollenhoven R, Klareskog L, Trollmo C, Malmström V. $\mathrm{CD} 25$ brightCD4+ regulatory $\mathrm{T}$ cells are enriched in inflamed joints of patients with chronic rheumatic disease. Arthritis Res Ther. 2004; 6(4):R335-46.

42. Cao D, Börjesson O, Larsson P, Rudin A, Gunnarsson I, Klareskog L, et al. FOXP3 identifies regulatory CD25bright CD4+ T cells in rheumatic joints. Scand J Immunol. 2006; 63(6):444-52.

43. Ehrenstein MR, Evans JG, Singh A, Moore S, Warnes G, Isenberg DA, et al. Compromised function of regulatory $\mathrm{T}$ cells in rheumatoid arthritis and reversal by anti-TNFalpha therapy. J Exp Med. 2004; 200(3):277-85.

44. Nistala K, Moncrieffe H, Newton KR, Varsani H, Hunter P, Wedderburn LR Interleukin-17-producing $\mathrm{T}$ cells are enriched in the joints of children with arthritis, but have a reciprocal relationship to regulatory $\mathrm{T}$ cell numbers. Arthritis Rheum. 2008; 58(3):875-87.

45. van Amelsfort JM, van Roon JA, Noordegraaf M, Jacobs KM, Bijlsma JW, Lafeber FP, et al. Proinflammatory mediator-induced reversal of CD4+,CD25+ regulatory T cell-mediated suppression in rheumatoid arthritis. Arthritis Rheum. 2007; 56(3):732-42.

46. Falcão PL, Malaquias LC, Martins-Filho OA, Silveira AM, Passos VM, Prata A, et al. Human Schistosomiasis mansoni: IL-10 modulates the in vitro granuloma formation. Parasite Immunol. 1998; 20(10):447-54.

47. Bacchetta R, Gambineri E, Roncarolo MG. Role of regulatory T cells and FOXP3 in human diseases. J Allergy Clin Immunol. 2007; 120(2):227-35.

48. Lavrnic D, Losen M, Vujic A, De Baets M, Hajdukovic LJ, Stojanovic V, et al. The features of myasthenia gravis with autoantibodies to MuSK. J Neurol Neurosurg Psychiatry. 2005; 76(8):1099-102
49. Qureschi AI, Choudhry MA, Akbar MS, Mohammad Y, Chua HC, Yahia AM, et al. Plasma exchange versus intravenous immunoglobulin treatment in myasthenic crisis. Neurology. 1999; 52(3):629-32.

50. Rønager J, Ravnborg M, Hermansen I, Vosrstrup S. Immunoglobulin treatment versus plasma exchange in patients with chronic moderate to severe myasthenia gravis. Artif Organs. 2001; 25(12):967-73.

51. Myasthenia Gravis Clinical Study Group. A randomized clinical trial comparing prednisone and azathioprine in myasthenia gravis. Results of the second interim analysis. J Neurol Neurosurg Psychiatry. 1993; 56(11):1157-63.

52. Falcão PL. Método e usos da técnica de citometria de fluxo para controle e acompanhamento de lesões musculares em atletas submetidos a esforço físico; abordagem imunológica e condicionamento físico. INPI. 2002, PI0206722-6.

53. Lindberg C, Andersen O, Lefvert AK. Treatment of myasthenia gravis with methylprednisolone pulse: a double blind study. Acta Neurol Scand. 1998; 97(6):370-3.

54. Palace J, Newsom-Davis J, Lecky B. A randomized double-blind trial of prednisolone alone or with azathioprine in myasthenia gravis. Myasthenia Gravis Study Group. Neurology. 1998; 50(6):1778-83.

55. Evoli A, Batocchi AP, Palmisani MT, Lo Monaco ML, Tonali P. Long-term results of corticosteroid therapy in patients with myasthenia gravis. Eur Neurol. 1992; 32(1):37-43.

56. Pereira ALC, Bolzani FCB, Stefani M, Charlín R. Uso sistêmico de corticosteróides: revisão da literatura. Med Cutan Iber Lat Am. 2007; 35(1):35-50.

57. Signore A, Soroa VA, De Vries EF. Radiobelled white blood cells or FDG for imaging of inflammation and infection? Q J Nucl Med Mol Imaging. 2009; 53(1):23-5.

58. Becker W, Meller J. The role of nuclear medicine in infection and inflammation. Lancet Infect Dis. 2001; 1(5):326-33.

59. Imam SK, Lin P. Radiotracers for imaging of infection and inflammation: a review. World J Nucl Med. 2006; 5(1):40-55

60. Gemmel F, Dumarey N, Welling M. Future diagnostic agents. Semin Nucl Med. 2009; 39(1):11-26.

61. Rennen HJJM, Boerman OC, Oyen WJG, Corstens FHM. Scintigraphy imaging of inflammatory processes. Curr Med Chem. 2002; 1(1):63-75.

62. Brasileiro CB, Cardoso VN, Ruckert B, Campos TPR. Avaliação de processos inflamatórios na articulação temporomandibular empregando leucócitos autólogos marcados com tecnécio-99m em modelo animal. Radiol Bras. 2006; 39(4):283-6.

63. Brasileiro CB, Pacheco CM, Queiroz-Junior CM, Lima CF, Silva JB, Campos TP. $(99 \mathrm{~m}) \mathrm{Tc}$-labeled-1-thio-beta-d-glucose as a new tool to temporomandibular joint inflammatory disorders diagnosis. Appl Radiat Isto. 2010; 68(12):2261-7.

64. Campos TPR, Brasileiro CB, Maia MJO. Radiofármaco e suas composições para cintilografia de sítios inflamatórios e infecciosos. INPI 2010, PI0904754-9.

65. Maia MJO, Campos TPR. Síntese e caracterização do 99mTc-5-thio-d-glicose para SPECT. In: Anais do 21 CBEB2008. Rio de Janeiro: SBEB; 2008. v. 1, p. 1-8.

66. Dalmázio I, Campos TPR. Compostos de coordenação metal-sacarídeo para terapia e diagnóstico. INPI 2010, PI1005216-0.

67. Kaneyama K, Segami NT, Sun W, Sato J, Fujimura K. Analysis of tumor necrosis factor- $\alpha$, interleukin- 6 , interleukin- $1 \beta$, soluble tumor necrosis factor receptors I e II, interleukin-6 soluble receptor, interleukin-1 soluble receptor type II, interleukin-1 receptor antagonist, and protein in the synovial fluid of patients with temporomandibular joint disorders. Oral Surg Oral Med Oral Pathol Oral Radiol Endod. 2005; 99(3):276-84.

68. Sukedai M, Tominaga K, Habu M, Matsukawa A, Nishihara T, Fukuda J Involvement of tumor necrosis factor-alpha and interleukin-8 in antigeninduced arthritis of the rabbit temporomandibular joint. J Oral Pathol Med. 2004; 33(2):102-10

69. Rennen HJ, Boerman OC, Oyen WJ, Corsten FH. Kinetics of 99m Tc-labeled interleukin-8 in experimental inflammation and infection. J Nucl Med. 2003; 44(9):1502-9 